\title{
AKRUAL
}

Jurnal Akuntansi

http://fe.unesa.ac.id/ojs/index.php/akrl

\section{STUDI KOMPARATIF KINERJA BANK SYARIAH DAN \\ BANK KONVENSIONAL DALAM MENGHADAPI KRISIS GLOBAL BERDASARKAN RASIO KEUANGAN}

\author{
Rohmawati Kusumaningtias \\ Universitas Negeri Surabaya \\ E-mail: rohmawatikusnitia@yahoo.co.id
}

Artikel diterima: 4 Agustus 2010

Revisi terakhir: 29 September 2010

\begin{abstract}
At the time of financial crisis, one of the influential institutions in society is banking. Banking sector provide soft loans to create productive employment for the community. On the other hand, customers also need the liquidity from banking. These stakeholders' needs can be met by looking at the performance of banking. This study aims to determine differences in the performance of sharia banking and conventional banking during economic crisis. This study uses t-test to analyze the data. From the research, it was found that in general, the performance of conventional banking is better than sharia banking in the economic crisis.
\end{abstract}

Keywords: shariah banking, conventional banking, performance.

\section{PENDAHULUAN}

\section{Latar Belakang Masalah}

Krisis ekonomi global yang berlangsung sejak 2008 diperkirakan akan berlanjut hingga 2010, perkiraan pertumbuhan ekonomi dunia pada 2009 maksimal 0,5 persen, demikian menurut pengamat ekonomi dari Universitas Muhammadiyah Yogyakarta (UMY) Ahmad Ma`ruf (Antara News; 2009). Untuk mengurangi dampak negatif krisis ekonomi global di dalam negeri banyak upaya yang harus dilakukan, antara lain dengan mengubah target penyerapan tenaga kerja pada 2009 menjadi menciptakan lapangan kerja produktif, menjaga usaha mikro, kecil, dan menengah (UMKM) agar tetap hidup dan berkembang, serta mendorong pertumbuhan industri yang kreatif. Lembaga yang terkait dengan upaya-upaya tersebut adalah perbankan.

Sektor perbankan menyediakan kredit lunak untuk menciptakan lapangan kerja produktif bagi masyarakat, terutama untuk usaha mikro kecil dan menengah. Menurut Undang-undang Perbankan No. 10 Tahun 1998, bank adalah badan usaha yang menghimpun dana dari masyarakat dalam bentuk simpanan dan menyalurkannya kepada masyarakat dalam bentuk kredit dan atau bentuk-bentuk lainnya dalam rangka meningkatkan taraf hidup rakyat banyak. Sedangkan pengertian Bank Umum adalah bank yang melaksanakan kegiatan usaha secara konvensional dan atau berdasarkan prinsip usaha syariah yang dalam kegiatannya memberikan jasa dalam lalu-lintas pembayaran. Fungsi yang ada dapat dikatakan 
bahwa dasar beroperasinya bank adalah kepercayaan masyarakat terhadap perbankan. Selain itu untuk menjaga kepercayaan tersebut, manajemen bank perlu meningkatkan kinerjanya untuk menjaga tingkat kesehatan bank.

Dalam perkembangan perekonomian Indonesia, perbankan syariah muncul di Indonesia pada 1992 yang merupakan hal baru dalam kerangka mekanisme sistem perbankan pada umumnya. Perbankan syariah lahir sebagai alternatif sistem perbankan guna memenuhi harapan yang menginginkan sistem keuangan syariah, yaitu bank yang menerapkan prinsip bagi hasil yang bebas dari riba. Karakteristik inilah yang membedakan bank syariah dengan bank konvensional. Perkembangan perbankan syariah saat ini dan ke depan diperkirakan akan memiliki produk dan jasa perbankan yang semakin beragam dan kompleks, sehingga risiko yang dihadapi juga meningkat. Sejak perbankan Islam beroperasi di lingkungan yang sama dengan bank konvensional, mereka menjadi pesaing satu dengan lainnya. Ironisnya, bagi perbankan syariah, persaingan tidak hanya dengan bank konvensional saja, tetapi juga dengan bank konvensional yang mempunyai unit syariah. Keada-an tersebut tentu menuntut perbankan syariah untuk meningkatkan kinerjanya.

Kelangsungan hidup suatu perbankan (going concern) merupakan hal yang terus diharapkan terjadi secara berkelanjutan oleh pelaku usaha yang terkait (stakeholder). Salah satu ukuran untuk menentukan tingkat kesehatan bank dapat ter-lihat dari kinerja laporan keuangan. Pada masa krisis ekonomi global ini, pelaku usaha harus bersifat hati-hati dalam setiap tindakan investasi bisnis. Sejarah perbankan pada saat krisis ekonomi 1997 memberikan pembelajaran yang sangat bermanfaat. Pada tahun tersebut banyak nasabah yang melakukan penarikan dana simpanan maupun investasi secara besar-besaran (rush) akibat hilangnya kepercayaan masyarakat terhadap likuiditas perbankan nasional. Belajar dari hal tersebut, maka diperlukan kenyamanan dan keamanan bagi para pemegang saham, pemegang surat berharga, peminjam, dan para penyimpan dana yang memercayakan uangnya pada sektor perbankan. Terlebih lagi jika memberikan keuntungan yang signifikan kepada stakeholder.

Dalam menghadapi krisis ekonomi, perusahaan pada umumnya mempunyai berbagai strategi manajemen untuk tetap dapat bertahan dalam menghasilkan keuntungan. Penelitian ini tidak membahas mengenai macam-macam strategi untuk menghadapi krisis global. Namun membandingkan hasil dari penerapan strategi-strategi tersebut dalam bentuk kinerja perbankan melalui analisis laporan keuangan. Karena dari laporan keuangan, kondisi, dan produktivitas perbankan sudah dapat terlihat melalui rasio-rasio keuangan yang menggambarkan usaha manajemen untuk tetap mengasilkan laba positif. Hasil dari penelitian ini diharapkan memberikan kontribusi positif bagi pelaku usaha dan masyarakat untuk memilih perbankan yang aman dan terpercaya melalui pengukuran kinerja keuangan.

\section{Perumusan Masalah}

Dari latar belakang yang telah dijelaskan, maka rumusan masalahnya adalah bagaimana perbedaan kinerja bank syariah dan bank konvensional dalam menghadapi krisis global dengan menggunakan rasio keuangan? 


\section{Tujuan Penelitian}

Penelitian ini bertujuan untuk menjelaskan perbedaan kinerja bank syariah dan bank konvensional dalam menghadapi krisis global dengan menggunakan rasio keuangan.

\section{KAJIAN PUSTAKA}

\section{Kinerja Bank dan Analisis Rasio Keuangan}

Kinerja bank secara keseluruhan merupakan gambaran prestasi yang dicapai bank dalam operasionalnya, yang menyangkut aspek keuangan, pemasaran, penghimpunan dan penyaluran dana, teknologi, serta sumber daya manusia. Kinerja keua-ngan bank merupakan gambaran kondisi keuangan bank pada satu periode tertentu yang diukur dengan indikator kecukupan modal, likuiditas, dan profitabilitas bank (Jumingan, 2006).

Kinerja menunjukkan sesuatu yang berhubungan dengan kekuatan dan kelemahan suatu perusahaan. Kekuatan tersebut dipahami agar dapat dimanfaatkan dan kelemahan juga harus diketahui agar dapat dilakukan langkahlangkah per-baikan. Dengan mengadakan perbandingan kinerja perusahaan terhadap standar yang ditetapkan atau dengan periode-periode sebelumnya atau dengan perusahaan dalam satu industri (perbankan) maka akan dapat diketahui kemajuan dan ke-munduran perusahaan.

Analisis rasio keuangan merupakan analisis dengan jalan membandingkan satu pos dengan pos laporan keuangan lainnya baik secara individu maupun bersama-sama guna mengetahui hubungan di antara pos tertentu, baik dalam neraca maupun laporan laba rugi (Jumingan, 2006). Analisis rasio keuangan dapat di-gunakan sebagai alat untuk mengevaluasi kinerja dan kondisi kesehatan keuangan perusahaan (Darsono dan Ashari, 2004).

\section{Rasio untuk Mengukur Permodalan Bank}

Rasio ini sering disebut juga sebagai analisis solvabilitas, atau disebut juga sebagai Capital Adequency Analysis. Tujuan utama analisis ini yaitu untuk mengetahui:

a. Permodalan bank yang ada telah mencukupi untuk mendukung kegiatan bank yang akan dilakukan secara efisien.

b. Permodalan bank tersebut akan mampu untuk menyerap kerugian-kerugian yang tidak dapat dihindarkan.

c. Kekayaan bank semakin besar atau mengecil.

Untuk dapat mengukur kemampuan permodalan tersebut dapat menggunakan rumus sebagai berikut (Dendawijaya, 2005) :

\section{CAR $=$ Equity Capital-Aktiva Tetap $\times 100 \%$ \\ Total Loans + Securities}

Rumus ini digunakan untuk mengukur kemampuan permodalan yang ada untuk menutup kemungkinan kerugian di dalam kegiatan perkreditan dan perdagangan surat-surat berharga. Apabila nilai CAR mencapai $8 \%$ maka bank tersebut sudah dapat dika-takan sehat, semakin rendah nilai CAR maka keadaan bank tersebut semakin buruk. 


\section{Rasio untuk Mengukur Likuiditas Bank}

Wood dan Porter, dalam (Mulyono, 1995) memberikan pengertian likuiditas suatu bank dalam bukunya Analysis of Bank Financial Statements yaitu sebagai berikut: "Bank liquidity is its ability to met deposit withdrawls, ma-turing it is liabilities and loan request without delay," disimpulkan bahwa likui-ditas suatu bank merupakan kemampuan bank tersebut untuk membayar atau memenuhi kewajiban dan pinjaman yang telah jatuh tempo. Berbagai rumus yang dapat digunakan untuk mengukur likuiditas bank secara kuantitatif dengan cara sebagai berikut:

$$
\text { LDR }=\frac{\text { Total kredit yang diberikan }}{\text { Dana pihak ketiga }} \times 100 \%
$$

Rumus ini digunakan untuk mengetahui tingkat kemampuan bank dalam membayar kembali penarikan dana yang dilakukan deposan dengan mengandalkan kredit yang diberikan sebagai sumber likuidasinya. Dendawijaya (2005) menyatakan bahwa batas kewajaran angka LDR (Loan to Deposit Ratio) adalah di bawah $110 \%$ yang berarti jumlah kredit yang disalurkan sama dengan jumlah dana masyarakat yang dapat dikumpulkan bank, sehingga kondisi bank tersebut sehat. Batasan tersebut juga sesuai dengan Surat Edaran Bank Indonesia No.26/5/BPP tanggal 29 Mei 1993.

\section{Rasio untuk Mengukur Rentabilitas Bank}

Terdapat tiga rasio rentabilitas atau profitabilitas yang dapat dibaca langsung dari laporan laba rugi dalam persentase yang umum (Dendawijaya, 2005), yaitu:

a. NIM

Rumus ini digunakan untuk mengukur kemampuan manajemen bank dalam mengelola aktiva produktifnya untuk menghasilkan pendapatan bunga bersih. Standar terbaik untuk NIM (Net Interest Margin) adalah sebesar 6\%, semakin besar nilainya maka semakin positif kondisi bank tersebut.

b. BOPO

$$
\mathrm{NIM}=\frac{\text { Pendapatan Bungan Bersih }}{\text { Rata-rata Aktiva Produktif }} \times 100 \%
$$

Rumus ini digunakan untuk mengukur perbandingan biaya operasional terhadap pendapatan operasi yang diperoleh bank. Batasan minimum BOPO yang telah ditentukan Bank Indonesia berdasarkan SK No. 30/11/KEP/DIR tanggal 30April 1997 adalah lebih kecil dari 100\%. Semakin kecil rasio BOPO maka semakin baik kondisi bank tersebut.

$$
\mathrm{BOPO}=\frac{\text { Biaya Operasional }}{\text { Pendapatan Operasional }} \times 100 \%
$$

c. ROA

Rumus yang digunakan untuk mengukur kemampuan bank dalam menciptakan laba dengan menggunakan seluruh aktiva yang dimiliki bank. Batasan minimum ROA yang ditentukan oleh Bank Indonesia adalah $1 \%$. Apabila bank tersebut memiliki ROA lebih besar dari 1\% maka bank tersebut dapat dikata-kan produktif mengelola aktiva sehingga menghasilkan laba, dan bank terse-but dalam kondisi sehat. Standar terbaik untuk ROA adalah 1,5\%.

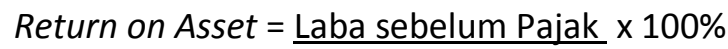

Rata-rata Total Assets 


\section{METODE PENELITIAN \\ Desain Penelitian}

Penelitian kuantitatif adalah penelitian ilmiah yang sistematis terhadap bagianbagian dan fenomena serta hubungan-hubungannya. Tujuan penelitian kuantitatif adalah mengembangkan dan menggunakan model-model matematis, teori-teori atau hipotesis yang berkaitan dengan fenomena alam. Proses pengukuran adalah bagian yang sentral dalam penelitian kuantitatif karena hal ini memberikan hubungan yang fundamental antara pengamatan empiris dan ekspresi matematis dari hubungan-hubungan kuantitatif. Penelitian ini menggunakan uji- $t$ untuk menguji purata (mean) dari sampel dengan asumsi data terdistribusi normal.

\section{Populasi dan Sampel}

Teknik pengambilan sampel pada penelitian ini dengan menggunakan sampling purposive. Pengertian Sampling purposive adalah teknik penentuan sampel dengan pertimbangan tertentu (Sugiyono; 2006). Dalam penelitian ini pertimbangan sampel didasarkan bahwa perbankan yang terdaftar di Bank Indonesia yang berupa bank devisa. Bank devisa adalah bank yang memperoleh surat penunjukan dari Bank Indonesia untuk dapat melakukan kegiatan usaha perbankan dalam valuta asing. Bank devisa dapat menawarkan jasa-jasa bank yang berkaitan dengan mata uang asing tersebut seperti transfer ke luar negeri, jual beli valuta asing, transaksi ekspor-impor, dan jasa-jasa valuta asing lainnya. Syarat-syarat yang harus dipenuhi sebelum suatu bank nondevisa dapat diberikan izin untuk menjadi bank devisa, antara lain: a. CAR minimum dalam bulan terakhir $8 \%$; b. tingkat kesehatan selama 24 bulan terakhir berturut-turut tergolong sehat; c. modal disetor minimal Rp. 150 miliar; d. bank telah melakukan persiapan untuk melaksanakan kegiatan sebagai Bank Umum Devisa meliputi: organisasi, sumber daya manusia, pedoman operasional kegiatan devisa.

\section{Teknik Pengumpulan Data dan Instrumen Penelitian}

Data yang digunakan dalam penelitian ini adalah data sekunder yaitu data yang diperoleh bukan langsung dari sumbernya dan bukan diusahakan sendiri oleh penulis atau peneliti. Metode pengumpulan data yang digunakan dalam penelitian ini adalah metode dokumentasi. Metode dokumentasi adalah mencari data mengenai hal-hal atau variabel berupa cacatan, transkip, buku, surat kabar, majalah, prasasti, notulen rapat, agenda, dan sebagainya (Arikunto; 2003). Data dalam penelitian ini merupakan data yang bersumber dari laporan keuangan periode 2006-2008 pada sampel.

Sedangkan instrumen penelitannya adalah sebagai berikut:

1) $\quad$ CAR $=$ Equity Capital-Aktiva Tetap $\times 100 \%$

Total Loans + Securities

$$
\mathrm{NIM}=\frac{\text { Pendapatan Bungan Bersih }}{\text { Rata-rata Aktiva Produktif }} \times 100 \%
$$

3) $\quad L D R=$ Total kredit yang diberikan $\times 100 \%$

Dana Pihak ke-3

$$
\text { BOPO }=\frac{\text { Biaya Operasional }}{\text { Pendapatan Operasional }} \times 100 \%
$$




$$
\text { Return on Asset }=\frac{\text { Laba sebelum Pajak }}{\text { Rata-rata Total Assets }}
$$

\section{Teknik Analisis Data}

Untuk menjawab rumusan masalah, data hasil penelitian akan dianalisis menggunakan independent samples t-test. Langkah pertama yang dilakukan adalah menghitung rasio keuangan (CAR, LDR, NIM, BOPO, dan ROA) untuk masingmasing bank dari 2006-2008. Kemudian menghitung rata-rata rasio keuangan tersebut untuk tiga tahun. Proses selanjutnya dilakukan analisis menggunakan independent samples t-test. Dan terakhir dilakukan interpretasi atas hasil uji-t yang dilakukan.

\section{HASIL DAN PEMBAHASAN}

\section{Hasil Penelitian}

Penelitian ini bertujuan untuk membandingkan kinerja keuangan pada perbankan syariah dan perbankan konvensional. Kinerja merupakan hal penting yang harus dicapai oleh setiap perusahaan, karena kinerja merupakan cerminan dari kemampuan perusahaan dalam mengelola dan mengalokasikan sumber daya yang dimiliki. Untuk mengetahui kinerja tersebut dalam penelitian ini menggunakan ukuran CAR, LDR, NIM, BOPO, dan ROA. Berikut ini merupakan hasil dari analisis yang telah dilakukan menggunakan independent samples $t$-test.

\section{a) CAR}

Rumus ini digunakan untuk mengukur kemampuan permodalan yang ada untuk menutup kemungkinan kerugian dalam kegiatan perkreditan dan perdagangan surat-surat berharga. Apabila nilai CAR mencapai $8 \%$ maka bank tersebut sudah dapat dikatakan sehat, semakin rendah nilai CAR maka keadaan bank terse-but semakin buruk. Analisis dilakukan dengan langkah-langkah sebagai berikut:

1) Menghitung nilai CAR untuk masing-masing bank selama 2006, 2007, dan 2008.

2) Menghitung rata-rata CAR untuk masing-masing bank selama tiga tahun.

3) Analisis rata-rata CAR menggunakan independent samples t-test.

4) Menginterpretasi hasil.

Karena hasil Levene's Test menyatakan bahwa asumsi kedua variance sama besar (equal variances assumed) terpenuhi, maka digunakan adalah hasil uji-t dua sampel independen dengan asumsi kedua variance sama besar untuk hipotesis $\mathrm{H}_{0}$ : $\mu_{1} \leq \mu_{2}$ terhadap $H_{1}: \mu_{1}>\mu_{2}$, yang memberikan nilai $\mathrm{t}=1.659$ dengan derajat kebebasan $\mathrm{n}_{1}+\mathrm{n}_{2}-2=2+15-2=15$ dan $p$-value $(2$-tailed $)=0.118$. Karena $p$-value lebih besar dari $\alpha=0,05$, maka $\mathrm{H}_{0}: \mu_{1} \leq \mu_{2}$ diterima. Sehingga dapat disimpulkan bahwa nilai rata-rata CAR perbankan syariah lebih kecil dari rata-rata CAR perbankan konvensional. 
b) LDR

Rumus ini digunakan untuk mengetahui tingkat kemampuan bank dalam membayar kembali penarikan dana yang dilakukan deposan dengan mengandalkan kredit yang diberikan sebagai sumber likuidasinya. Dendawijaya (2005) menyatakan bahwa batas kewajaran angka LDR (Loan to Deposit Ratio) adalah di bawah $110 \%$ yang berarti jumlah kredit yang disalurkan sama dengan jumlah dana masyarakat yang dapat dikumpulkan bank, sehingga kondisi bank tersebut sehat. Batasan tersebut juga sesuai dengan Surat Edaran Bank Indonesia No.26/5/BPP tanggal 29 Mei 1993. Analisis LDR dilakukan dengan langkah-langkah sebagai berikut:

1) Menghitung nilai LDR untuk masing-masing bank selama 2006, 2007, dan 2008.

2) Menghitung rata-rata LDR untuk masing-masing bank selama tiga tahun.

3) Analisis rata-rata LDR menggunakan independent samples t-test.

4) Menginterpretasi hasil.

Karena hasil Levene's Test menyatakan bahwa asumsi kedua variance sama besar (equal variances assumed) terpenuhi, maka digunakan adalah hasil uji-t dua sampel independen dengan asumsi kedua variance sama besar untuk hipotesis $\mathrm{H}_{0}$ : $\mu_{1} \leq \mu_{2}$ terhadap $\mathrm{H}_{1}: \mu_{1}>\mu_{2}$, yang memberikan nilai $\mathrm{t}=0.966$ dengan derajat kebebasan $\mathrm{n}_{1}+\mathrm{n}_{2}-2=2+15-2=15$ dan $p$-value $(2$-tailed $)=0.349$. Karena $p$-value lebih besar dari $\alpha=0,05$, maka $\mathrm{H}_{0}: \mu_{1} \leq \mu_{2}$ diterima. Sehingga dapat disim-pulkan bahwa nilai rata-rata LDR perbankan syariah lebih kecil dari rata-rata LDR perbankan konvensional.

c) NIM

Rumus ini digunakan untuk mengukur kemampuan manajemen bank dalam mengelola aktiva produktifnya untuk menghasilkan pendapatan bunga bersih. Standard terbaik untuk NIM (Net Interest Margin) adalah sebesar 6\%, semakin besar nilainya maka semakin positif kondisi bank tersebut. Analisis LDR dilakukan dengan langkah-langkah sebagai berikut:

1) Menghitung nilai NIM untuk masing-masing bank selama 2006, 2007, dan 2008.

2) Menghitung rata-rata NIM untuk masing-masing bank selama tiga tahun.

3) Analisis rata-rata NIM menggunakan independent samples t-test.

4) Menginterpretasi hasil.

Karena hasil Levene's Test menyatakan bahwa asumsi kedua variance sama besar (equal variances assumed) terpenuhi, maka digunakan adalah hasil uji-t dua sampel independen dengan asumsi kedua variance sama besar untuk hipotesis $\mathrm{H}_{0}$ : $\mu_{1} \leq \mu_{2}$ terhadap $\mathrm{H}_{1}: \mu_{1}>\mu_{2}$, yang memberikan nilai $\mathrm{t}=1.199$ dengan derajat kebebasan $\mathrm{n}_{1}+\mathrm{n}_{2}-2=2+15-2=15$ dan $p$-value $(2$-tailed $)=0.249$. Karena $p$-value lebih besar dari $\alpha=0,05$, maka $\mathrm{H}_{0}: \mu_{1} \leq \mu_{2}$ diterima. Sehingga dapat disim-pulkan bahwa nilai rata-rata NIM perbankan syariah lebih kecil dari rata-rata NIM perbankan konvensional.

d) $\mathrm{BOPO}$

Rumus ini digunakan untuk mengukur perbandingan biaya operasional terhadap pendapatan operasi yang diperoleh bank. Batasan minimum BOPO yang telah ditentukan Bank Indonesia berdasarkan SK No. 30/11/KEP/DIR tanggal 30 
April 1997 adalah lebih kecil dari 100\%. Semakin kecil rasio BOPO maka semakin baik kondisi bank tersebut. Analisis BOPO dilakukan dengan langkahlangkah sebagai berikut:

1) Menghitung nilai BOPO untuk masing-masing bank selama 2006, 2007, dan 2008.

2) Menghitung rata-rata $B O P O$ untuk masing-masing bank selama tiga tahun.

3) Analisis rata-rata BOPO menggunakan independent samples t-test.

4) Menginterpretasi hasil.

Karena hasil Levene's Test menyatakan bahwa asumsi kedua variance sama besar (equal variances assumed) terpenuhi, maka digunakan adalah hasil uji-t dua sampel independen dengan asumsi kedua variance sama besar untuk hipotesis $\mathrm{H} 0$ : $\mu_{1} \leq \mu_{2}$ terhadap $\mathrm{H}_{1}: \mu_{1}>\mu_{2}$, yang memberikan nilai $\mathrm{t}=0.455$ dengan derajat kebebasan $\mathrm{n}_{1}+\mathrm{n}_{2}-2=2+15-2=15$ dan $p$-value $(2$-tailed $)=0.655$. Karena $p$-value lebih besar dari $\alpha=0,05$, maka $\mathrm{H}_{0}: \mu_{1} \leq \mu_{2}$ diterima. Sehingga dapat disimpulkan bahwa nilai rata-rata BOPO perbankan syariah lebih kecil dari rata-rata BOPO perbankan konvensional.

e) ROA

Rumus ini digunakan untuk mengukur kemampuan bank dalam menciptakan laba dengan menggunakan seluruh aktiva yang dimiliki bank. Batasan minimum ROA yang ditentukan oleh Bank Indonesia adalah 1\%. Apabila bank tersebut memiliki ROA lebih besar dari $1 \%$ maka bank tersebut dapat dikatakan produktif mengelola aktiva sehingga menghasilkan laba, dan bank tersebut dalam kondisi sehat. Standar terbaik untuk ROA adalah 1,5\%. Analisis ROA dilakukan dengan langkah-langkah sebagai berikut:

1) Menghitung nilai ROA untuk masing-masing bank selama 2006, 2007, dan 2008.

2) Menghitung rata-rata ROA untuk masing-masing bank selama tiga tahun.

3) Analisis rata-rata ROA menggunakan independent samples t-test.

4) Menginterpretasi hasil.

Karena hasil Levene's Test menyatakan bahwa asumsi kedua variance sama besar (equal variances assumed) terpenuhi, maka digunakan adalah hasil uji-t dua sampel independen dengan asumsi kedua variance sama besar untuk hipotesis $\mathrm{H}_{0}$ : $\mu_{1} \leq \mu_{2}$ terhadap $\mathrm{H}_{1}: \mu_{1}>\mu_{2}$, yang memberikan nilai $\mathrm{t}=0.363$ dengan derajat kebebasan $\mathrm{n}_{1}+\mathrm{n}_{2}-2=2+15-2=15$ dan $p$-value $(2$-tailed $)=0.722$. Karena $p$-value lebih besar dari $\alpha=0,05$, maka $\mathrm{H}_{0}: \mu_{1} \leq \mu_{2}$ diterima. Sehingga dapat disimpulkan bahwa nilai rata-rata ROA perbankan syariah lebih kecil dari rata-rata ROA perbankan konvensional.

\section{Pembahasan}

Hasil uji hipotesis menunjukkan bahwa nilai CAR perbankan syariah lebih kecil dari perbankan konvensional. Nilai CAR mengindikasikan kemampuan modal perbankan untuk menutup kemungkinan rugi terhadap dana nasabah dan suratsurat berharga. Apabila nilai CAR mencapai $8 \%$ maka bank tersebut sudah dapat dikatakan sehat, semakin rendah nilai CAR maka keadaan bank tersebut semakin tidak sehat. Hal ini dikarenakan bank tersebut tidak memiliki modal yang cukup untuk menutup kerugian yang mungkin timbul atas dana para nasabah dan surat- 
surat berharga. Sebagaimana disyaratkan oleh bank Indonesia bahwa perbankan harus memiliki CAR minimal sebesar $8 \%$.

Perhitungan rata-rata (mean) kedua perbankan menunjukkan bahwa kedua jenis perbankan mempunyai nilai CAR lebih dari $8 \%$, yaitu perbankan syariah $23.58 \%$ dan perbankan konvensional $11.74 \%$. Sehingga secara umum kedua kelompok perbankan dinilai sehat. Meskipun terdapat nilai minus untuk Bank Century, namun kinerja CAR perbankan konvensional masih lebih unggul dari perbankan syariah. Hal ini mengindikasikan bahwa perbankan konvensional lebih mampu untuk memberikan pelunasan lebih baik jika suatu saat terjadi kerugian.

Ukuran LDR merupakan ukuran likuiditas yang digunakan untuk mengetahui tingkat kemampuan bank dalam membayar kembali penarikan dana yang dilakukan deposan dengan mengandalkan kredit yang diberikan. Dendawijaya (2005) menyatakan bahwa batas kewajaran angka LDR (Loan to Deposit Ratio) adalah dibawah $110 \%$ yang berarti jumlah kredit yang disalurkan sama dengan jumlah dana masyarakat yang dapat dikumpulkan bank, sehingga kondisi bank tersebut sehat. Hal ini mengartikan bahwa semakin kecil nilai LDR maka kondisi per-bankan akan semakin sehat. Dari hasil uji statistik menyatakan bahwa nilai LDR perbankan syariah lebih kecil dari perbankan konvensional. Dengan demikian perbankan syariah lebih sehat dari perbankan konvensional. Artinya jika terjadi penarikan dana nasabah secara mendadak, maka perbankan syariah dapat melunasi lebih cepat, karena aliran keuangan yang lebih likuid.

Analisis selanjutnya adalah pengukuran NIM. Ukuran ini digunakan untuk mengetahui kemampuan manajemen bank dalam mengelola aktiva produktifnya untuk menghasilkan pendapatan bunga bersih. Standard terbaik untuk NIM adalah sebesar 6\%, semakin besar nilainya maka semakin positif kondisi bank tersebut. Dari hasil uji Ho, dinyatakan bahwa NIM perbankan syariah lebih kecil dari perbankan konvensional. Artinya bahwa manajemen bank konvensional lebih baik dalam mengelola aktiva produktif yang dimiliki untuk menghasilkan pendapatan bunga yang lebih tinggi.

Selanjutnya pengukuran BOPO digunakan untuk mengetahui perbandingan biaya operasional terhadap pendapatan operasi yang diperoleh bank. Batasan minimum BOPO yang telah ditentukan Bank Indonesia berdasarkan SK No. 30/11/KEP/DIR tanggal 30April 1997 adalah lebih kecil dari 100\%. Semakin kecil rasio BOPO maka semakin baik kondisi bank tersebut. Secara umum untuk kedua kelompok perbankan dinyatakan dalam kondisi yang baik. Karena untuk nilai mean BOPO keduanya berada di bawah $100 \%$, yaitu untuk perbankan syariah $63.45 \%$ dan untuk perbankan konvensional $58.66 \%$. Sedangkan untuk uji $\mathrm{H}_{0}$ dinyatakan bahwa perbankan syariah lebih kecil nilainya dari perbankan konvensional. Hal ini mengindikasikan bahwa perbankan syariah dapat menekan biaya operasionalnya menjadi lebih kecil untuk menghasilkan laba yang lebih baik.

Pengukuran selanjutnya berkaitan dengan solvabilitas perbankan, penelitian ini menggunakan ROA. ROA digunakan untuk mengukur kemampuan bank dalam menciptakan laba dengan menggunakan seluruh aktiva yang dimiliki bank. Batasan minimum ROA yang ditentukan oleh Bank Indonesia adalah 1\%. Apabila bank tersebut memiliki ROA lebih besar dari $1 \%$ maka bank tersebut dapat 
dikatakan produktif mengelola aktiva sehingga menghasilkan laba, dan bank tersebut dalam kondisi sehat. Standar terbaik untuk ROA adalah 1,5\%.

Secara umum, kedua perbankan berada di posisi yang terbaik. Nilai mean ROA perbankan syariah adalah 1,9\%, perbankan konven-sional adalah 1,6\%. Hasil uji Ho, dinyatakan bahwa perbankan syariah mempunyai nilai ROA lebih kecil dibandingkan dengan perbankan konvensional. Artinya, perbankan konvensional lebih produktif dalam menggunakan aktivanya untuk mencapai laba yang maksimal. Hal ini sejalan dengan analisis NIM seperti yang telah dijelaskan di atas.

Untuk lebih memudahkan melakukan simpulan, maka berikut ini disajikan tabel 1 yang merangkum hasil analisis uji statistik beserta pembahasannya. Dari tabel tersebut, diharapkan simpulan yang bersifat generalisasi dapat diambil untuk mendukung rumusan masalah.

Setelah membaca Tabel 1, secara umum, kedua kelompok perbankan dinyatakan sehat. Kedua perbankan tersebut mempunyai keunggulan di masingmasing pengukuran. Tidak ada yang lebih unggul untuk satu kelompok perbankan pada semua pengukuran. Untuk perbankan konvensional lebih baik dalam ukuran CAR, NIM, dan ROA. Artinya, untuk kecukupan modal dan produktivitas penggunaan aktiva dalam menghasilkan laba perbankan konvensional lebih baik. Sementara untuk ukuran LDR dan BOPO, yang mengindikasikan likuiditas dana nasabah dan efisiensi biaya operasional, perbankan syariah lebih ung-gul.

Untuk menjawab rumusan masalah, maka harus melihat terlebih dahulu definisi kinerja. Kinerja keuangan bank merupakan gambaran kondisi keuangan bank pada satu periode tertentu yang diukur dengan indikator kecukupan modal, likuiditas, dan profitabilitas bank (Jumingan; 2006). Dalam hal ini dapat diartikan bahwa perbankan konvensional dalam menghadapi krisis global memiliki kinerja yang lebih unggul dari perbankan syariah. Karena dua indikator, yaitu kecukupan modal dan profitabilitas yang lebih baik dari perbankan syariah. Sementara untuk likuiditas, meskipun lebih kecil namun, masih dalam kategori sehat. 
Tabel 1

Ringkasan Hasil Penelitian dan Pembahasan

\begin{tabular}{|c|c|c|c|c|c|}
\hline \multirow[t]{2}{*}{ Ukuran } & \multirow[t]{2}{*}{ Kegunaan } & \multicolumn{2}{|c|}{ Hasil Statistik } & \multirow[t]{2}{*}{ Batas } & \multirow[t]{2}{*}{ Interpretasi } \\
\hline & & Mean & Uji t & & \\
\hline CAR & $\begin{array}{l}\text { Mengukur kecukupan modal } \\
\text { terhadap penarikan dana } \\
\text { nasabah }\end{array}$ & $\begin{array}{l}23.58 \% \\
11.74 \%\end{array}$ & $\begin{array}{c}\text { Ho } \\
\text { diterima }\end{array}$ & $\begin{array}{l}\geq 8 \% \text {. Semakin } \\
\text { besar semakin } \\
\text { sehat. }\end{array}$ & $\begin{array}{l}\text { Keduanya dinyatakan sehat. Hasil Uji-t mengindikasikan bahwa permodalan yang } \\
\text { dimiliki perbankan konvensional lebih tinggi nilainya dari perbankan syariah. } \\
\text { Sehingga jika suatu saat terjadi kerugian, maka dana nasabah dalam perbankan } \\
\text { konvensional akan dapat dilunasi sepenuhnya oleh perbankan konvensional. }\end{array}$ \\
\hline LDR & $\begin{array}{l}\text { Mengukur tingkat likuiditas } \\
\text { perbankan }\end{array}$ & $\begin{array}{l}90.2 \% \\
74.3 \%\end{array}$ & $\begin{array}{c}\text { Ho } \\
\text { diterima }\end{array}$ & $\begin{array}{l}\leq 110 \% \\
\text { Semakin kecil } \\
\text { semakin sehat. }\end{array}$ & $\begin{array}{l}\text { Keduanya dinyatakan sehat. Hasil uji-t menyatakan bahwa nilai LDR perbankan } \\
\text { syariah lebih kecil dari perbankan konvensional. Dengan demikian, maka } \\
\text { perbankan syariah lebih sehat dari perbankan konvensional. Yang artinya, bahwa } \\
\text { jika terjadi penarikan dana nasabah secara mendadak, maka perbankan syariah } \\
\text { dapat melunasi lebih cepat, karena aliran keuangan yang lebih likuid. }\end{array}$ \\
\hline NIM & $\begin{array}{l}\text { Mengukur produktitivitas } \\
\text { aktiva dalam mengahasilkan } \\
\text { pendapatan bersih }\end{array}$ & $\begin{array}{l}7.33 \% \\
5.23 \%\end{array}$ & $\begin{array}{c}\text { Ho } \\
\text { diterima }\end{array}$ & $\begin{array}{l}\geq 6 \% \text {. } \\
\text { Semakin tinggi } \\
\text { semakin } \\
\text { positif. }\end{array}$ & $\begin{array}{l}\text { Standar terbaik adalah } 6 \% \text {. Meskipun perbankan konvensional hanya } 5.23 \% \text { tetapi } \\
\text { masih dinyatakan positif. Untuk uji t dinyatakan bahwa NIM perbankan syariah } \\
\text { lebih kecil dari perbankan konvensional. Yang artinya bahwa manajemen bank } \\
\text { konvensional lebih baik dalam mengelola aktiva produktif yang dimiliki untuk } \\
\text { menghasilkan pendapatan bunga yang lebih tinggi. }\end{array}$ \\
\hline BOPO & $\begin{array}{l}\text { Mengukur kemampuan bank } \\
\text { dalam meminimalkan biaya } \\
\text { operasional terhadap } \\
\text { pendapatan operasional }\end{array}$ & $\begin{array}{l}63.45 \% \\
58.66 \%\end{array}$ & $\begin{array}{c}\text { Ho } \\
\text { diterima }\end{array}$ & $\begin{array}{l}\leq 100 \% \\
\text { Semakin kecil } \\
\text { semakin baik. }\end{array}$ & $\begin{array}{l}\text { Keduanya dinyatakan dalam kondisi yang baik. Hasil uji t menyatakan bahwa } \\
\text { perbankan syariah lebih kecil nilainya dari perbankan konvensional. Hal ini } \\
\text { mengindikasikan bahwa perbankan syariah dapat menekan biaya operasionalnya } \\
\text { menjadi lebih efisien untuk menghasilkan laba yang lebih baik. }\end{array}$ \\
\hline ROA & $\begin{array}{l}\text { Mengukur kemampuan bank } \\
\text { dalam memaksimalkan } \\
\text { aktiva untuk menghasilkan } \\
\text { laba }\end{array}$ & $\begin{array}{l}1.9 \% \\
1.6 \%\end{array}$ & $\begin{array}{c}\text { Ho } \\
\text { diterima }\end{array}$ & $\begin{array}{l}\geq 1 \% \text { Semakin } \\
\text { tinggi semakin } \\
\text { sehat. }\end{array}$ & $\begin{array}{l}\text { Keduanya dinyatakan sehat. Hasil uji t menyatakan bahwa perbankan syariah } \\
\text { mempunyai nilai ROA lebih kecil dibandingkan dengan perbankan konvensional. } \\
\text { Artinya, perbankan konvensional lebih produktif dalam menggunakan aktivanya } \\
\text { untuk mencapai laba yang maksimal. }\end{array}$ \\
\hline
\end{tabular}




\section{SIMPULAN}

1. Secara umum, kedua kelompok perbankan dinyatakan sehat. Lebih lanjut, kedua perbankan tersebut mempunyai keunggulan di masing-masing pengukuran. Tidak ada yang lebih unggul untuk satu kelompok perbankan pada semua pengukuran. Untuk perbankan konvensional lebih baik dalam ukuran CAR, NIM, dan ROA. Artinya, untuk kecukupan modal dan produktivitas penggunaan aktiva dalam menghasilkan laba perbankan konvensional lebih baik. Sementara untuk ukuran LDR dan BOPO, yang mengindikasikan likuiditas dana nasabah dan efisiensi biaya operasional, perbankan syariah lebih unggul.

2. Untuk menjawab rumusan masalah, maka harus melihat terlebih dahulu definisi kinerja. Kinerja keuangan bank merupakan gambaran kondisi keuangan bank pada satu periode tertentu yang diukur dengan indikator kecukupan modal, likuiditas, dan profitabilitas bank (Jumingan, 2006). Dalam hal ini dapat di-artikan bahwa perbankan konvensional dalam menghadapi krisis global memiliki kinerja yang lebih unggul dari perbankan syariah. Karena dua indikator, yaitu kecukupan modal dan profitabilitas yang lebih baik dari perbankan syariah. Sementara untuk likuiditas, meskipun lebih kecil namun, masih dalam kategori sehat.

\section{SARAN}

1. Pada saat krisis global, perbankan konvensional mempunyai kinerja yang lebih baik dari perbankan syariah, maka bagi masyarakat akan lebih aman jika menyimpan di perbankan konvensional. Namun akan lebih baik jika masyarakat mampu membaca laporan keuangan, maka diinterpretasikan terlebih dahulu dalam hal pemilihan bank umum. Terutama pada sisi penggunaan alokasi dana nasabah.

2. Perbankan syariah supaya lebih meningkatkan lagi kinerja keuangannya, terutama dari sisi profitabilitas. Profitabilitas perbankan syariah yang lebih kecil disebabkan karena tujuan utama pendirian bank syariah adalah untuk bermitra dengan pengusaha. Hal ini bisa dilihat dari kredit (pembiayaan) yang disalurkan, sebagian besar adalah pada sektor riil (produktif). Berbeda halnya dengan perbankan konvensional yang lebih tinggi dalam sektor moneter (konsumtif). Artinya, perbankan syariah lebih mengutamakan unsur kemitraan dalam sisi kredit (pembiayaan) yang nantinya akan meningkatkan pendapatan mitra. Dan jika pendapatan mitra meningkat maka secara tidak langsung akan memengaruhi pendapatan perbankan syariah. Namun secara realitas, lebih baik jika perbankan syariah juga mampu memberi terobosan dengan manajemen yang baik sehingga profitabilitasnya tidak kalah dengan perbankan konvensional.

3. Untuk penelitian lebih lanjut bisa dilakukan dengan mencari hal-hal yang memengaruhi profitabilitas perbankan syariah secara kuantitatif dan dilanjutkan dengan mencari solusi atau cara-cara terbaik untuk meningkatkan profitabilitas perbankan syariah dengan penelitian yang bersifat kualitatif.

4. Untuk penelitian lebih lanjut dapat juga dilakukan dengan memasukkan kelebihan perbankan syariah dari sisi pembiayaan yang bersifat nonriba dengan penelitian yang bersifat kuantitatif atau kualitatif. 


\section{DAFTAR PUSTAKA}

AntaraNews.com. Pengamat Perkirakan Krisis Global Hingga 2010. Diakses 5 April 2009.

Arikunto, Suharsimi. 2003. Prosedur Penelitian Suatu Pendekatan Praktek Edisi Revisi V. Jakarta : Rineka Cipta.

Bashir, Abdul-Hamed M, 2001. Assesing The Performance of Islamic Banks: Some Evidence from the Middle East. New Orleans; Annual meeting of the MEEA/American economic Association.

Darsono dan Ashari. 2004. Pedoman Praktis Memahami Laporan Keuangan. Yogyakarta: Penerbit Andi.

Dendawijaya, Lukman. 2005. Manajamen Perbankan. Bogor; Ghalia

Herrero dan Santabarbara. 2008. Does The Chinese Banking System Benefit from Foreign Investors? http://ssrn.com/abstract_id=1151209.

Jumingan. 2006. Analisis Laporan Keuangan. Jakarta: PT Bumi Aksara.

Muhammad. 2005. Manajemen Bank Syariah. Yogyakarta : UPP AMP YKPN.

. 2005. Pengantar Akuntansi Syariah. Jakarta : Salemba Empat

Mulyono, Teguh Pudjo. 1995. Analisa Laporan Keuangan untuk Perbankan Edisi Revisi. Jakarta; Djambalan.

Sugiyono. 2006. Statistika untuk Penelitian. Bandung: Alfabeta.

Surat Edaran Bank Indonesia No.26/5/BPP tanggal 29 Mei 1993.

Surat Keputusan No. 30/11/KEP/DIR tanggal 30April 1997

Undang-undang No.10 Tahun 1998 tentang Perbankan. 